\title{
Mechanical regulation of chondrogenesis
}

\author{
Christopher J O'Conor ${ }^{1,2}$, Natasha Case ${ }^{1}$ and Farshid Guilak ${ }^{1,2^{*}}$
}

\begin{abstract}
Mechanical factors play a crucial role in the development of articular cartilage in vivo. In this regard, tissue engineers have sought to leverage native mechanotransduction pathways to enhance in vitro stem cell-based cartilage repair strategies. However, a thorough understanding of how individual mechanical factors influence stem cell fate is needed to predictably and effectively utilize this strategy of mechanically-induced chondrogenesis. This article summarizes some of the latest findings on mechanically stimulated chondrogenesis, highlighting several new areas of interest, such as the effects of mechanical stimulation on matrix maintenance and terminal differentiation, as well as the use of multifactorial bioreactors. Additionally, the roles of individual biophysical factors, such as hydrostatic or osmotic pressure, are examined in light of their potential to induce mesenchymal stem cell chondrogenesis. An improved understanding of biomechanically-driven tissue development and maturation of stem cell-based cartilage replacements will hopefully lead to the development of cell-based therapies for cartilage degeneration and disease.
\end{abstract}

Keywords: Osteoarthritis, Cartilage defect, Scaffold, Tissue engineering, Mesenchymal stem cell, Adipose stem cell, Regeneration, Synovial joint, Ion channel, Mechanical signal transduction

\section{Introduction}

Musculoskeletal tissues are highly sensitive to their mechanical environment, allowing them to adapt to the physical demands of their environment. Mechanical factors can influence the structure and function of these tissues at all stages of life, including development, growth, remodeling, injury and disease, and repair [1-4]. In particular, chondrocytes and chondroprogenitors have been shown to transduce and respond to a wide array of mechanical stimuli both during development as well as throughout adulthood, including deformation, shear, fluid flow, streaming potentials, hydrostatic pressure, and osmotic pressure [1,2,5-7].

Similarly, there is growing interest in understanding the mechanobiology of multipotent stem cells, which are abundant, expandable, and available from various tissue depots including bone marrow, fat, and synovium [8-10]. The cells are capable of chondrogenic differentiation, and provide a potential cell source for the regeneration and replacement of damaged articular cartilage resulting from injury or diseases such as osteoarthritis [11-14]. However, an effective

\footnotetext{
* Correspondence: guilak@duke.edu

'Department of Orthopaedic Surgery, Duke University Medical Center, 375 MSRB Box 3093, Durham, NC 27710, USA

${ }^{2}$ Department of Biomedical Engineering, University of North Carolina Chapel Hill, Chapel Hill, NC 27599, USA
}

cell-based tissue replacement requires a stably differentiated cell population capable of producing and maintaining a functional neo-tissue. There is great interest in leveraging these native mechanical and biophysical cues to enhance the current strategies for stem cell-based cartilage tissue repair. This review summarizes recent progress on the use of mechanical and biophysical signals to influence the chondrogenic differentiation of stem cell-based cartilage replacements. Furthermore, we discuss several candidate transduction mechanisms that may play a role in the process of biomechanically-induced chondrogenesis, in the hope that a better understanding of the pathways behind the mechanosensitivity of stem cells will lead to more practical, reliable, and effective methods of leveraging these pathways for cartilage tissue engineering [15].

\section{Mechanical stimulation of chondrogenesis}

The current literature on in vitro mechanical stimulation of chondrogenesis encompasses a broad variety of scaffolds, cell types, and bioreactors, making it challenging to draw definitive conclusions across studies. This section focuses primarily on the most common model system of dynamic compressive loading of bone marrow-derived mesenchymal stem cells (MSCs) supported by synthetic foam and/or hydrogel scaffolds (summarized in Table 1). Of course, 
future comparative analyses of studies involving other bioreactors and scaffold systems will probably be needed to further understand the mechanisms behind mechanical signals and chondrogenesis. Furthermore, investigations into the mechanical responses of stem cells sourced from other tissues of interest (adipose, synovium) will also be necessary to move them towards clinical applications, as it is currently unclear whether these stem cells utilize the same mechanisms of mechanical signal transduction as bone marrow-derived MSCs.

Mechanical stimulation can directly influence the fate of undifferentiated stem cells [1-3,5-7,26]. Dynamic compressive loading, specifically cyclic unconfined compression, has been one of the most highly utilized model systems of mechanical stimulation in cartilage tissue engineering and mechanobiology [7]. This system has also been used to investigate the potential of mechanical stimulation for use in MSC-based cartilage regeneration and repair, and the results of these studies can be summarized by four main findings: growth factor treatment is a more potent stimulus than mechanical stimulation for initiating MSC differentiation; provided there is a period of predifferentiation and other specific loading parameters, mechanical stimulation can be effective at enhancing growth-factor induced MSC differentiation and tissue neo-formation; the mechanoresponsiveness of differentiated MSC constructs appears to persist over time to direct matrix remodeling and maintain a stable chondrogenic phenotype; and bioreactors that impart multifactorial mechanical stimulation, such as compression-shear loading, further enhance mechanicallyinduced chondrogenesis.

\section{Mechanically-induced chondrogenesis in the absence of exogenous growth factors}

In general, the effects of dynamic compressive loading alone (that is, in the absence of exogenous growth factors) on MSC chondrogenesis appear to be minimal and transient, particularly in comparison with growth factor treatment alone. For example, although dynamic loading of MSC-laden constructs increased aggrecan promoter activity and sulfated glycosaminoglycan (sGAG) accumulation, exposure to transforming growth factor beta (TGF $\beta$ ) alone led to far greater sGAG accumulation compared with disks loaded in the absence of growth factors [17]. Kisiday and colleagues similarly observed that while loading without growth factors led to increased sGAG compared with the unloaded control, TGF $\beta$ alone led to a much greater increase in sGAG content, as well as an increase in collagen content [18]. The chondrogenic effects of loading on MSCs in the absence of growth factors also appear to be transient. For example, while loading in the absence of growth factors increased Col2 $\alpha 1$ and aggrecan gene expression after 1 and 2 weeks of loading, expression of these chondrogenic markers returned to baseline levels after an additional week of continued loading [19].

Primary chondrocytes, in comparison, maintain a stable chondrogenic phenotype in three-dimensional culture, and can produce an appreciable amount of functional matrix $[27,28]$ even in the absence of growth factors or serum $[29,30]$. However, the literature on the effects of loading on chondrocytes cultured in growth factor and serum-free conditions is limited, and therefore difficult to compare with what is known about growth factor-free and serum-

Table 1 Summary of recent dynamic compressive loading studies evaluating chondrogenesis in mesenchymal stem cells

\begin{tabular}{|c|c|c|c|c|c|c|}
\hline Bioreactor & Compressive loading regimen & Scaffold & Species (age) & $\begin{array}{l}\text { Medium } \\
\text { supplementation }\end{array}$ & $\begin{array}{l}\text { Preculture } \\
\text { (days) }\end{array}$ & Reference \\
\hline Compression & $1 \mathrm{~Hz}, 10 \%, 1$ to 20 hours & Agarose & Bovine & \pm Dex $\pm T G F \beta_{1}$ & 8 or 16 & {$[16]$} \\
\hline Compression & 0.33 to $3 \mathrm{~Hz}, 10 \%, 1$ to 3 hours & Agarose & $\begin{array}{l}\text { Bovine ( } 3 \text { to } \\
6 \text { months) }\end{array}$ & $\operatorname{Dex} \pm \mathrm{TGF} \beta_{3}$ & 3 & {$[17]$} \\
\hline $\begin{array}{l}\text { Compression } \\
\text { (semipermeable) }\end{array}$ & $\begin{array}{l}0.3 \mathrm{~Hz}, 7.5 \%, 45 \text { minutes on/ } \\
45 \text { minutes rest }\end{array}$ & Agarose & $\begin{array}{l}\text { Horse }(2 \text { to } \\
5 \text { years) }\end{array}$ & $\operatorname{Dex} \pm \mathrm{TGF} \beta_{1}$ & 0 & {$[18]$} \\
\hline Compression & 0.01 to $1 \mathrm{~Hz}, 10 \%, 1$ to 4 hour/day & Agarose & $\begin{array}{l}\text { Bovine ( } 3 \text { to } \\
6 \text { months) }\end{array}$ & $\operatorname{Dex} \pm \mathrm{TGF} \beta_{3}$ & 0 or 21 & {$[19]$} \\
\hline Compression + shear & 0.1 to $1 \mathrm{~Hz}, 5$ to $20 \%, 1$ hour/day & Fibrin/PU & Human & Dex $\pm T G F \beta_{1}$ & 7 & {$[20]$} \\
\hline Compression & 1 Hz, 10\%, 1 hour/day & Agarose & $\begin{array}{l}\text { Porcine } \\
\text { (4 months) }\end{array}$ & $\mathrm{Dex} \pm \mathrm{TGF} \beta_{3}$ & 0 or 21 & {$[21]$} \\
\hline Compression + shear & $1 \mathrm{~Hz}, 10$ to 20\%, 1 hour/day & Fibrin/PU & Human & None & 2 to 4 & {$[22]$} \\
\hline Compression & $1 \mathrm{~Hz}, 10 \%, 1$ hour & Agarose & $\begin{array}{l}\text { Porcine } \\
\text { (4 months) }\end{array}$ & $\mathrm{Dex}+\mathrm{TGF} \beta_{3}$ & $0,7,14,21$ & {$[23]$} \\
\hline Compression + shear & $0.1 \mathrm{~Hz}, 5$ to 20\%, 3 hours/day & Agarose & $\begin{array}{l}\text { Bovine ( } 3 \text { to } \\
6 \text { months) }\end{array}$ & Dex $\pm \mathrm{TGF} \beta_{3}$ & 21 & {$[24]$} \\
\hline Compression & $1 \mathrm{~Hz}, 10 \%, 4$ hours/day & $\begin{array}{l}\text { Hyaluronic } \\
\text { acid }\end{array}$ & Human & Dex + TGF $\beta_{1}$ & 3 & {$[25]$} \\
\hline
\end{tabular}


free loading of MSC-laden constructs. Loading of chondrocyte-laden disks in the presence of low levels $(0.2$ and $2 \%$ ) of fetal bovine serum produced no change in sGAG production, but decreased functional properties of the constructs [31]. In contrast, a large positive effect on matrix accumulation and functional properties was observed in another study with chondrocyte-laden constructs loaded in serum-free conditions [30]. Interestingly, both bovine MSCs and chondrocytes embedded in agarose and precultured for 3 days in growth-factor-free medium were able to respond to dynamic loading with an increase in aggrecan promoter activity [17], suggesting that a similar mechanism of mechanotransduction in chondrocytes may be present, to some degree, in undifferentiated stem cells. Nevertheless, in the case of MSCs, dynamic compressive loading alone appears to be insufficient for inducing appreciable differentiation and matrix production in the absence of growth-factor stimulation, and therefore is not, as yet, a suitable substitute for growth-factor-induced stem cell differentiation.

\section{Culture conditions that support mechanically-induced chondrogenesis}

Dynamic loading in the presence of growth factors can significantly enhance MSC chondrogenic differentiation, particularly if a chondrogenic preculture period is provided.
For example, while loading of MSCs after 8 days of preculture in TGF $\beta$ and dexamethasone-supplemented medium did not increase aggrecan or Col $2 \alpha 1$ gene expression or sGAG or protein synthesis, loading after an additional 8 days (16 days in total) of preculture increased all of these measures [16]. Of note, the effects of loading were more limited when dexamethasone was not added. By preculturing constructs for $0,7,14$, and 21 days in the presence of TGF $\beta$ and dexamethasone and then assessing the gene response immediate following 1 hour of loading, Haugh and colleagues observed that generally later time points ( 7 and 21 days) of preculture resulted in the greatest relative increases in core aggrecan and Col $2 \alpha 1$ expression compared with unloaded controls [23]. Likewise, the annular cell population also demonstrated a dependence on 14 or 21 days of preculture to exhibit a loading-induced enhancement of Col $2 \alpha 1$ and aggrecan expression. In a similarly designed study, loading was initiated both immediately following construct creation as well as after 3 weeks of preculture, all in the presence of TGF $\beta$ and dexamethasone. While continuous loading elicited negative effects on DNA, sGAG, and collagen content, 3 weeks of chondrogenic preculture completely abrogated these negative effects, as well as leading to improvements in functional properties and extracellular matrix distribution (Figure 1) [19]. Yet another study observed similar detrimental effects of loading without preculture on sGAG content and dynamic
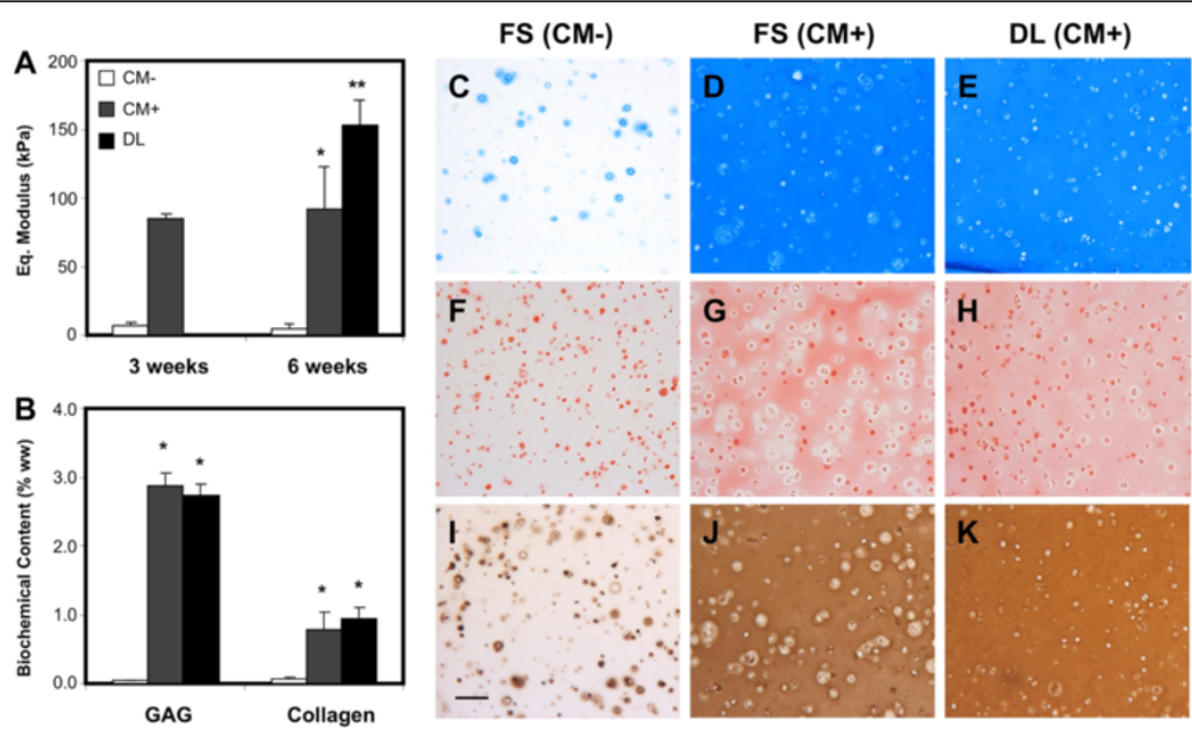

Figure 1 Delayed dynamic compressive loading improves mechanical properties and extracellular matrix distribution without increasing biochemical content. Following 3 weeks of chondrogenic preculture, dynamic compressive loading was applied daily to human mesenchymal stem cell (MSC)-agarose constructs for 3 weeks. (A) The equilibrium modulus of MSC-seeded constructs was higher in medium containing transforming growth factor beta (TGF $\beta ; C M+$ ) compared with culture without TGF $\beta$ (CM-) at 3 and 6 weeks; dynamic loading (DL) in CM + for 3 weeks further improved mechanical properties. (B) Biochemical content of dynamically loaded constructs at week 6 was not different compared with $\mathrm{CM}+$ controls. (C) to (E) Alcian Blue staining at week 6 showed equal distribution of proteoglycans between $\mathrm{CM}+$ controls and loaded constructs with weak staining in CM- controls. (F) to (H) Picrosirius Red staining and (I) to (K) collagen type II immunostaining showed more homogeneous distribution of collagen in loaded constructs compared with controls. Scale bar: $100 \mu \mathrm{m}$. ${ }^{*}$ Greater than $\mathrm{CM}-\mathrm{controls}(P<0.05)$. ** Greater than CM + controls $(P<0.05)$. FS, free swelling. Reproduced from [19] with kind permission from eCM journal [32]. 
modulus, as well the attenuation of this negative effect with delayed loading [21].

Beyond the application of growth factors and the duration of preculture, the response of MSCs to dynamic loading has been found dependent on a number of other factors as well, including duty cycle and loading frequency. An extended loading regime totaling 12 hours of loading per day reduced sulfate and protein incorporation [18]. A separate study observed no effect of 20 hours of continuous loading on sGAG or protein synthesis after an 8-day preculture [16]. Interestingly, significant increases in these measures were observed after 16 days of chondrogenic preculture, indicating a dependence on differentiation status and construct maturation on the response to mechanical factors. The frequency of dynamic loading is also a critical parameter that may influence chondrogenic responses. For example, increases in the functional properties of MSC-laden constructs were observed with $1 \mathrm{~Hz}$ dynamic compressive loading, but were absent at lower frequencies of mechanical stimulation [19]. Given that chondrocytes also exhibit a high sensitivity to duty cycle and loading frequency [33,34], further optimization of loading parameters may be able to improve mechanicallydriven MSC chondrogenesis and matrix accumulation.

\section{Mechanical regulation of neo-cartilage maintenance and turnover}

While current methods of mechanical stimulation do not appear to have an especially large effect on bulk matrix accumulation during growth factor-induced maturation of MSC-laden constructs, there have been stronger indications for the importance of mechanical signals on MSC-based neo-cartilage maintenance. Normal matrix metabolism, such as aggrecan turnover [35] and collagen reorganization and remodeling in response to loading, has probably been an underappreciated metric for cartilage tissue engineering. For example, a gene array analysis found that 413 genes associated with chondrogenesis were upregulated, versus 139 that were downregulated, with 3 weeks of dynamic loading of MSC constructs that had been precultured for 3 weeks [19]. Furthermore, mechanical loading differentially regulated genes specifically involved in matrix remodeling and organization, such as matrix metalloproteinases, tissue inhibitors of metalloproteinases, and cross-linking proteins, suggesting that this coordinated response may have led to the enhanced pericellular and extracellular matrix distribution and organization, as well as the improved functional properties, observed in the loaded constructs [19]. Again, we can compare this matrix remodeling response of MSCs with the native response of chondrocytes undergoing delayed, long-term loading, where functional property increases are elicited with delayed loading in the absence of any changes in bulk matrix content [36]. Indeed, the similarity of MSCs to chondrocytes in terms of their long-term response to loading may represent an additional characteristic of the sustained chondrogenic differentiation in this system. However, since the conventional assays performed in the majority of cartilage mechanobiology and tissue engineering papers are largely insensitive to long-term matrix remodeling and turnover, more work will be needed to confirm mechanically-driven matrix remodeling and maintenance in MSC-laden constructs.

\section{Mechanical stimulation and the maintenance of chondrogenesis}

Another critical issue of long-term MSC culture is the ossification and hypertrophic differentiation of chondrogenicallyinduced MSC constructs upon implantation [37]. Establishing a stable, articular chondrocytic phenotype is therefore another critical design goal of cartilage tissue engineering. Col1 gene expression is one marker of hypertrophic or osteogenic differentiation, and has been examined in response to loading $[23,25]$. For example, the accumulation of Coll in the annulus of constructs was found to decrease with loading after 21 days of preculture [23], while other studies showed that dynamic compressive loading suppressed a number of other hypertrophic markers such as collagen type 10, matrix metalloproteinase-13, and alkaline phosphatase gene expression, as well as the calcium content of constructs exposed to hypertrophic factors [25]. Few studies have examined the effects of loading on terminal differentiation of chondrogenically-induced MSCs, so these preliminary findings will need to be followed up with more comprehensive studies.

\section{Multimodal bioreactors for enhancing mechanically- induced chondrogenesis}

Mechanical loading of the joint produces a complex environment in articular cartilage in vivo, consisting of a diverse array of tensile, shear, and compressive stresses and strains, in addition to other physicochemical effects $[7,38]$. Accordingly, bioreactors that impose additional components of mechanical stimulation have been examined for their potential to further induce and support chondrogenic differentiation. Adding a component of shear to compressive loading has been shown to be superior to single-factor loading regimens at inducing matrix biosynthesis in chondrocytes [39], and this multifactorial strategy has more recently been applied to the study of MSC chondrogenesis. For example, a compression-shear bioreactor consisting of a rotating ceramic ball in contact with the surface of a construct that also transverses perpendicular to the surface was shown to enhance both Col $2 \alpha 1$ and aggrecan expression in the absence of exogenous growth factors, and also increased sGAG production, with or without exogenous TGF $\beta$ 
[20]. In addition, endogenous production of TGF $\beta$ was induced by this compression-shear loading in the absence of exogenous growth factors. Furthermore, a synergistic effect of compression and shear on Sox9 and Col $2 \alpha 1$ upregulation was observed (Figure 2) when this system was used to compare the effects of compressionshear with each component individually [22].

In other studies, another compression plus shear bioreactor, utilizing a spherical indenter that travels across the surface of the construct, enhanced Col $2 \alpha 1$ and aggrecan expression, in the presence or absence of TGF $\beta$, after 21-day chondrogenic preculture [24]. Furthermore, 21 days of additional slide-contact loading led to increases in sGAG and collagen content, a more uniform collagen distribution, and enhanced tensile properties. In addition, loaded constructs demonstrated a depth-dependent distribution of sGAG. In addition to their ability to promote anisotropy that is more similar to that of native cartilage, multifactorial bioreactors will help to further elucidate the roles of different mechanical stimuli, as well as their interactions. These systems also move a step closer to recreating the in vivo physical environment, and therefore may provide a system for predicting how cartilage tissue replacements will perform within a joint.

\section{Mechanisms of mechanically-induced \\ chondrogenesis \\ Physical transduction of mechanical loading}

There are obvious practical limitations to mechanically conditioning anatomically-shaped tissue replacements, including the spatial constraints and inhomogeneity of the stress and strain fields. Furthermore, these inhomogeneities can also act to obscure the detailed understanding of the cellular effects on mechanical signals. As such, there is a growing interest in studying the individual biophysical components present during deformational loading, which practically are much simpler to deliver in a repeatable and uniform manner. A thorough understanding of the mechanisms by which individual components of mechanical stimulation leads to cartilage development, maintenance, and disease should also allow for more practical and predicable strategies for enhancing the maturation of stem cell-based cartilage replacement tissues.

Joint loading leads to complex tissue strains, including components of compression, tension, and shear, producing direct cellular and nuclear deformation [40]. In addition, indirect biophysical factors are also generated (Figure 3) as a result of the exudation of interstitial water and ions from cartilage, including streaming potentials, changes in local pH and osmolarity, and hydrostatic pressure [38]. While application of dynamic compression to isolated chondrocytes or MSCs seeded into hydrogels or polymeric scaffolds will recapitulate many of these biophysical changes that occur in native cartilage, it is important to appreciate that the amount of extracellular matrix relative to the original scaffold or hydrogel present within the constructs, as well as the mechanical properties of these scaffolds, will influence the range of biophysical stimuli generated by loading (for example [41]). A number of studies have examined the response of chondrocytes and MSCs to individual biophysical stimuli generated during loading of intact articular cartilage. In this respect, future studies comparing donor-matched responses among chondrocytes, undifferentiated MSCs, and differentiated MSCs to these stimuli would be highly useful in further elucidating the mechanisms involved in mechanotransduction in different cell types.
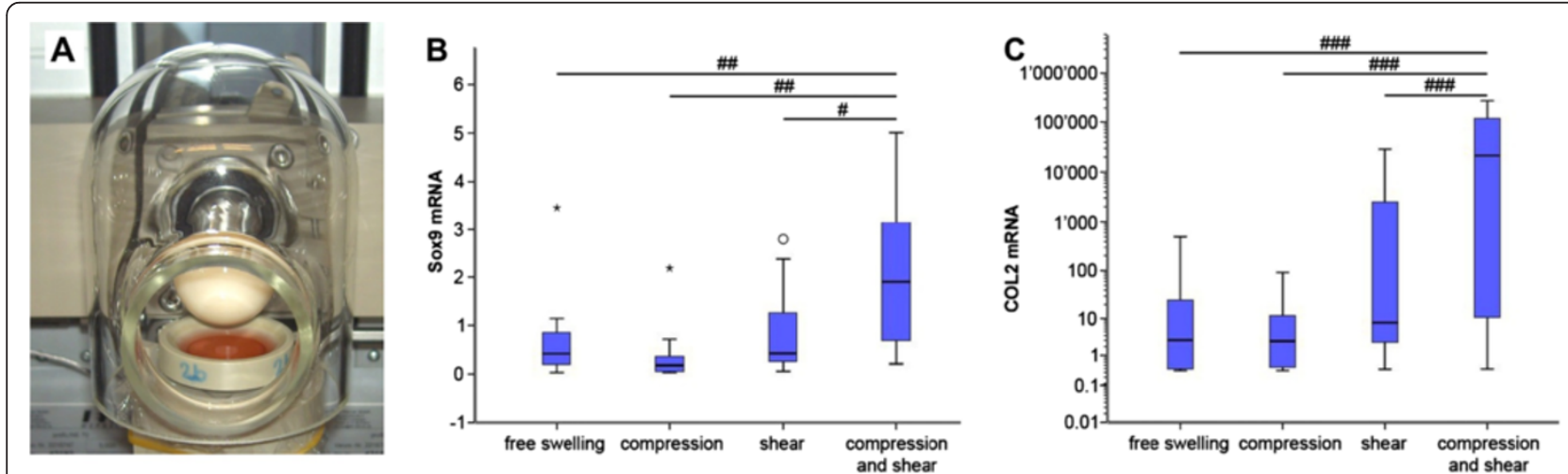

Figure 2 Mechanical loading using a multimodal bioreactor enhances mesenchymal stem cell chondrogenesis. (A) The bioreactor can apply both compression and shear to the cell-seeded construct through rotation of the ceramic hip ball in contact with the surface of the construct and through vertical movement of the ball perpendicular to the construct surface. Relative (B) Sox9 and (C) Col2 mRNA expression of human mesenchymal stem cells after culture for 21 days in fibrin/polyurethane constructs without exogenous growth factors. Although either compression or shear loading alone increased these chondrogenic markers above free swelling levels, the combination of shear and compression loading further enhanced the response. ${ }^{\#} P<0.05,{ }^{\# \#} P<0.01,{ }^{\# \#} P<0.001$. Reproduced from [22] with kind permission from eCM journal [32]. 


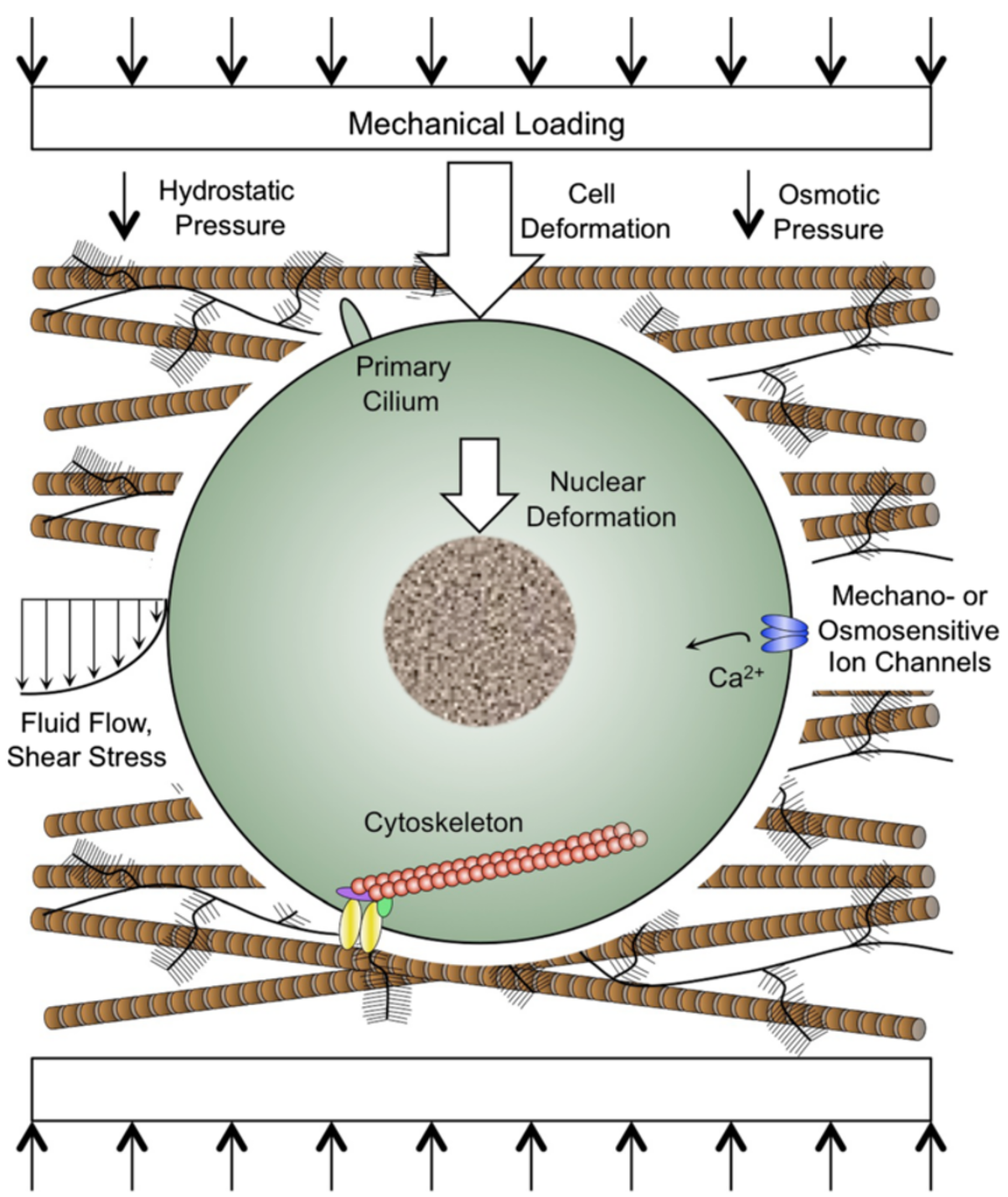

Figure 3 Mechanisms of mechanically-induced chondrogenesis. Joint loading produces complex tissue strains, which lead to direct cellular and nuclear deformation, and generates indirect biophysical factors, including osmotic and hydrostatic pressure and fluid flow. Mechanical loading of isolated chondrocytes or mesenchymal stem cells (MSCs) seeded into hydrogels or polymeric scaffolds may recapitulate many of the changes that occur in native cartilage. Candidate mechanical signal transducers in chondrocytes and MSCs include ion channels, the primary cilium, the nucleus, and the cytoskeleton.

\section{Cell deformation}

Mechanical loading of hydrogel scaffolds results in the transmission of strains to cells embedded within such constructs $[28,42]$. The relationship between ECM and cell-level strains in agarose-laden chondrocytes is also comparable with that of in situ chondrocytes in loaded cartilage explants [43] once a pericellular matrix has been elaborated. Lee and Bader observed that a $20 \%$ strain of day 0 chondrocyte-laden agarose constructs led to supraphysiological cell strains in chondrocytes cultured with or without serum, but that after 3 and 6 days of preculture the constructs cultured specifically with serum exhibited reduced cell strains, which were more similar with what occurs in situ [28]. They attributed this finding to enhanced pericellular matrix accumulation in the constructs cultured with serum, which was associated with increased pericellular sGAG staining with preculture. The requirement of a preculture period as well as growth factor treatment to facilitate loadinginduced enhancement of MSC chondrogenesis suggests that the pericellular matrix is also an important transducer of deformational compressive loading in stem cells.

Dynamic compressive loading of MSCs in agarose and similarly compliant scaffolds would also be expected to induce cellular and nuclear deformation, and further investigation into the mechanical properties of stem cells, stem cell nuclei, and the neo-pericellular matrix prior to, 
during, and after stem cell differentiation may help elucidate the roles of cell and nuclear deformation in the transduction of compressive loading. Unconfined compression also allows for radial expansion, and generates a degree of radial and circumferential tensile strains. Tensile loading also modulates stem cell differentiation, although this loading regime in isolation appears to stimulate a fibrochondrocyte phenotype [44-46].

\section{Hydrostatic pressure}

While peak physiologic levels of fluid pressurization in articular cartilage are in the order of 10 to $20 \mathrm{MPa}[47,48]$, compression of agarose hydrogels is predicted to generate only around $0.5 \mathrm{kPa}$ of hydrostatic pressure, due to the scaffold's high porosity [17]. With sufficient matrix elaboration, however, the fluid pressurization of agarose cylinders subjected to dynamic compressive loading [49] is predicted to resemble the increase in native loaded cartilage [50]. Nonetheless, fluid pressurization, even at high levels, is expected to induce little or no deformation of tissues and cells, due to the intrinsic incompressibility of water and the cartilage extracellular matrix [51]. To evaluate fluid pressurization as an isolated mechanical stimulus, in vitro bioreactors have been developed that directly pressurize the culture medium surrounding cell-seeded constructs, in the absence of cell or tissue deformation [6]. Alternatively, bioreactors can pressurize the gas phase above the culture medium, but one limitation of these types of bioreactors is that the partial pressures of gas in the culture medium are affected, and these bioreactors are less commonly used. Studies using systems that directly pressurize the culture medium have shown that isolated chondrocytes are responsive to hydrostatic pressure. Acute application of static hydrostatic pressure at $5 \mathrm{MPa}$ for 4 hours enhanced Col $2 \alpha 1$ and aggrecan expression by chondrocytes in agarose gels [52], while application of both dynamic and static hydrostatic pressure at $10 \mathrm{MPa}$ to scaffoldless chondrocyte constructs for 1 hour/day on days 10 to 14 of culture led to increased sGAG production and compressive stiffness at day 28 [53].

Applying dynamic hydrostatic pressurization (3 to $10 \mathrm{MPa}, 1 \mathrm{~Hz}$ ) to human MSCs either seeded within scaffolds or in pellet culture in the presence of TGF $\beta$ increased expression of cartilage extracellular matrix genes and enhanced biochemical content compared with TGF $\beta$ alone [54-56]. In these studies, hydrostatic pressure was applied by directly pressurizing the culture medium for 1 to 4 hours/day beginning in the first week of culture, indicating that the MSC response to hydrostatic loading does not require a preculture period. Miyanishi and colleagues examined the dose dependency of hydrostatic loading with TGF $\beta$ supplementation, and found that while $0.1 \mathrm{MPa}$ was sufficient to increase Sox9 expression, upregulation of Col $2 \alpha 1$ expression only occurred with loading at $10 \mathrm{MPa}$ [57]. Hydrostatic pressure also transiently increased cartilage-associated genes in the absence of TGF $\beta[55,58,59]$. Recent studies with rat MSCs cultured in alginate applied hydrostatic pressure following an initial 8-day preculture in chondrogenic medium including TGF $\beta$. Dynamic hydrostatic pressure applied by pressurization of the gas phase above the culture medium for 7 days at 13 to $36 \mathrm{kPa}$ and $0.25 \mathrm{~Hz}-$ parameters lower than in previous studies - increased expression of Col2 $\alpha 1$ and aggrecan, as well as sGAG accumulation, both in the absence and presence of TGF $\beta[60,61]$. Furthermore, in the absence of exogenous TGF $\beta$, hydrostatic pressure increased expression and secretion of $\mathrm{TGF} \beta_{1}$, as well as the phosphorylation of Smad2/3 and p38 mitogen-activated protein kinase. However, pharmacologic inhibition of TGF $\beta$ signaling only modestly reduced the upregulation of $\operatorname{Col} 2 \alpha 1$ by loading and had no influence on the upregulation of aggrecan by loading, suggesting the involvement of other signaling pathways in mediating the response to hydrostatic pressure [61].

\section{Osmotic pressure}

Healthy articular cartilage has an interstitial osmolarity ranging from 350 to $450 \mathrm{mOsm}$ due to the high concentration of negatively charged proteoglycans in the tissue, which attracts counterions [62]. Extracellular matrix production by articular chondrocytes has been shown to be sensitive to the medium osmolarity. Culture for 48 hours in 550 mOsm medium increased sGAG synthesis by chondrocytes in alginate beads relative to culture in 380 mOsm medium, while culture in 270 mOsm medium decreased sGAG synthesis [63]. Chondrocytes cultured in medium at 370 mOsm for 6 days exhibited the greatest sGAG accumulation and sGAG synthesis by chondrocytes in alginate compared with culture in medium with either higher or lower osmolarity [64]. Recent longer-term studies have indicated that neo-tissue formation by articular chondrocytes in hydrogel systems is influenced by osmolarity of the culture medium, but the results have been contradictory $[65,66]$. Freshly isolated chondrocytes in alginate accumulated less sGAG at 270 mOsm compared with osmolarities ranging from 380 to $550 \mathrm{mOsm}$ [65], while culture-expanded chondrocytes produced neo-tissue with superior mechanical properties when cultured in agarose at 300 mOsm compared with 400 mOsm [66].

Effects of osmolarity on extracellular matrix production may be due in part to regulation of the chondrocyte transcription factor Sox9. Treatment of freshly isolated chondrocytes from osteoarthritic human articular cartilage with hyperosmotic medium (550 mOsm vs. $380 \mathrm{mOsm}$ ) led to an increase in the levels of Sox 9 mRNA and protein, an effect mediated in part by an increase in the half-life of Sox9 mRNA with hyperosmotic exposure [67]. However, 
the level of Col2 $\alpha 1$ mRNA and its half-life were decreased by exposure to hyperosmotic conditions. Hyperosmotic medium also increased phosphorylation of p38 mitogenactivated protein kinase, and induction of Sox 9 mRNA by hyperosmotic treatment was disrupted in the presence of a pharmacologic inhibitor to p38 mitogen-activated protein kinase. A similar study in equine articular chondrocytes showed that hyperosmotic treatment had varying effects on Sox9 mRNA levels dependent on whether treatment was applied in a static or cyclic manner and whether chondrocytes were from normal or osteoarthritic cartilage [68].

In these studies with isolated chondrocytes, the osmolarity of the culture medium was kept constant. However, articular chondrocytes in situ are exposed to cyclic changes in osmolarity due to joint loading and unloading during normal daily activity. Compression of articular cartilage causes extrusion of water relative to solutes due to fixed charges on the sulfated GAG chains, which leads to an increase in tissue osmolarity. High-frequency loading, such as walking, as well as prolonged joint loading resulting in diurnal strains [69], will produce a dynamic osmotic environment on the time scale ranging from seconds to hours. Similar to hydrostatic pressure, the osmotic changes in chondrocyte and MSC-laden constructs in response to dynamic compressive loading should be minimal initially, but should increase with SGAG accumulation. Although there is evidence that dynamic hypotonic loading at $0.1 \mathrm{~Hz}$ may enhance cartilage matrix gene expression in chondrocytes in monolayer culture after 2 hours of loading [70], little is known regarding the long-term effects of dynamic or repetitive daily osmotic loading on neo-tissue matrix content and mechanical properties.

Growth and chondrogenic differentiation of MSCs are also influenced by culture medium osmolarity. Highosmolarity medium (485 mOsm) reduced proliferation of both rat MSCs and human adipose-derived stem cells $[71,72]$. Increasing the osmolarity of chondrogenic differentiation medium containing TGF $\beta$ by 100 mOsm enhanced Sox9, Col2 $\alpha 1$, and aggrecan expression, as well as expression of the hypertrophic chondrocyte markers Col10 and Runx2, in day 21 monolayer cultures of human MSCs [73]. Whether osmolarity influences matrix accumulation or functional properties of MSC-laden constructs remains to be investigated.

\section{Fluid flow}

Mechanical loading of the cartilage layer results in large gradients in hydrostatic pressure, which subsequently induce flow of the interstitial fluid within the extracellular matrix. One way that mechanical loading is predicted to enhance tissue maturation is through this flow-mediated nutrient and growth factor exchange, as well as through physical activation of growth factors [74]. Loading may also influence tissue maturation through direct transduction of fluid shear stress across the cellular membrane. Fluid flow in response to joint loading is complex and challenging to recapitulate for isolated chondrocytes in three-dimensional cultures. However, controlled medium flow has been used to culture chondrocyte-seeded constructs, as culture with dynamic fluid flow provides several advantages over static culture including enhanced mass transport, a more controlled biochemical environment, and the application of hydrodynamic stimuli. Perfusion and rotating wall bioreactors have been shown to enhance extracellular matrix accumulation by chondrocytes seeded in porous polymeric scaffolds [75-77]. Perfusion bioreactors have similarly been found to enhance the biochemical content of MSC-seeded constructs grown in chondrogenic medium including TGF $\beta[78,79]$. In another study, culture in an oscillating bioreactor that delivered slow, directional perfusion to MSC-woven poly( $\varepsilon$-caprolactone) constructs improved functional properties, increased type II collagen content, and supported more homogeneous matrix deposition (Figure 4) [80]. These studies indicate the importance of fluid flow on construct maturation, although it remains unclear whether flow-induced nutrient transport, growth factor activation, and/or direct cellular sensing are influencing cellular behavior.

\section{Molecular mechanisms of transduction}

The molecular mechanisms of mechanical signal transduction in chondrocytes and MSCs are not fully understood and represent an area of growing investigation. Ion channels, the primary cilium, the nucleus, and the cytoskeleton have all been proposed as candidate mechanical signal transducers in articular chondrocytes (Figure 3). Ion channels in chondrocytes include potassium channels, sodium channels, transient receptor potential (TRP) nonselective cation channels, and chloride channels [81]. Various ion channels in chondrocytes appear to be regulated by changes in osmolarity, as well as different forms of mechanical stimulation. For example, the TRPV4 ion channel has been identified as the major sensor of osmolarity in chondrocytes [82], and activation of this channel leads to an influx of calcium ions. Calcium signaling has also been observed in chondrocytes in response to hydrostatic pressurization [83] and compressive loading [84]. Changes in intracellular calcium downstream of ATP secretion and binding to purinergic receptors have also been proposed as a mechanical signaling pathway in chondrocytes [85]. Calcium signaling has been linked to the propagation of mechanical effects on gene expression in cartilage explants [86]. Treatment with nifedipine, a calcium channel inhibitor, or 4-aminopyridine, a potassium channel inhibitor, disrupted mechanical stimulation of sGAG synthesis by chondrocytes in agarose, suggesting possible roles for calcium and potassium signaling in mediating this loading 

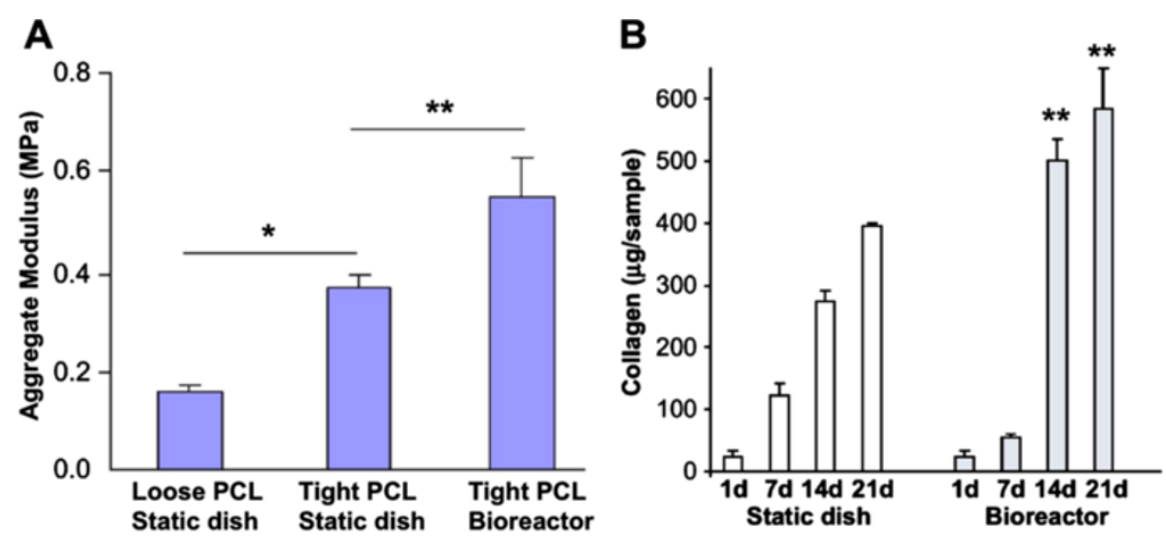

\section{C}
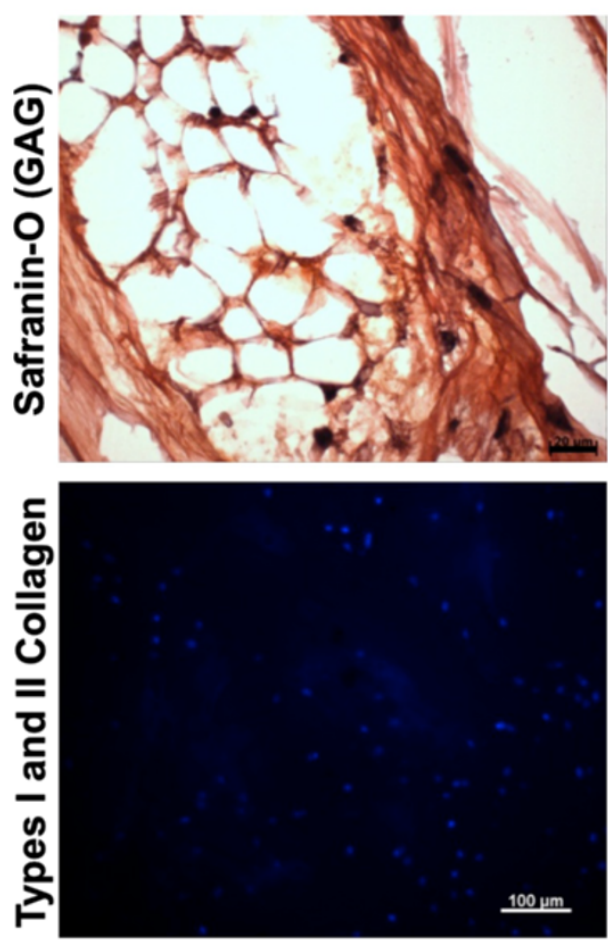

D
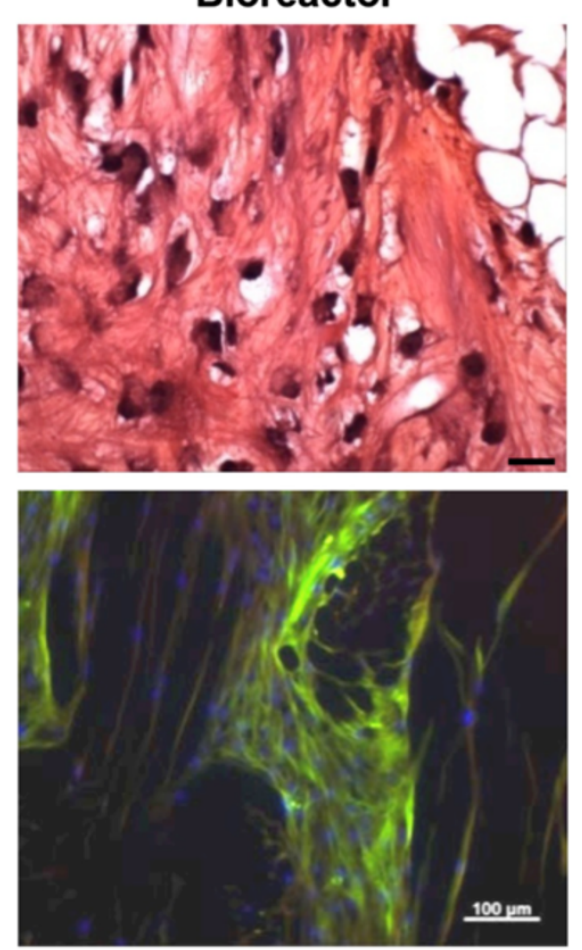

Figure 4 Culture in an oscillating bioreactor enhances tissue mechanical properties and collagen content. (A) Aggregate modulus and (B) total collagen content in human mesenchymal stem cell-poly( $\varepsilon$-caprolactone) (hMSC-PCL) constructs. *Significant difference due to scaffold structure $(P<0.05)$; ${ }^{*}$ Significant difference due to culture vessel $(P<0.05)$. (C), (D) Histological (top) and immunohistological (bottom) appearance of day 21 hMSC-PCL constructs cultured (C) statically or (D) in a bioreactor. Tissue sections were stained for safranin-O (top, scale bar:

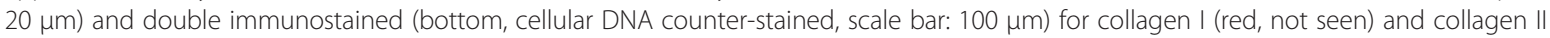
(green). GAG, glycosaminoglycan. Adapted from [80].

effect [87]. A recent study showed that altering the intracellular sodium and calcium concentrations using the pharmacologic agents oubain and ionomycin for 1 hour daily on days 10 to 14 of culture increased the tensile modulus of neo-tissue produced by chondrocytes from young bovine donors in a scaffoldless culture system at 4 weeks of culture, providing evidence that ion channel regulation can also influence functional properties of neocartilage [88].
The primary cilium is a nonmotile organelle that extends from the cell surface and has been implicated in both sensory and signaling functions in a variety of cells [89]. Primary cilia were identified on articular chondrocytes more than three decades ago [90,91], and recent work indicates that the primary cilium may have an important role in chondrocyte mechanotransduction [92,93]. Primary cilia on sternal chondrocytes were shown to have $\alpha_{2}, \alpha_{3}$, and $\beta_{1}$ 
integrins on their surface [94], allowing a direct linkage between the cilium and collagens in the surrounding pericellular matrix. As such, tissue compression during joint loading could lead to deformation of the cilium. Ion channels, including TRPV4, are also found on primary cilia. Interestingly, chemical disruption of the primary cilia on articular chondrocytes blocked the increase in intracellular calcium caused by exposure to hypo-osmotic stress or a TRPV4 channel agonist [82]. Acute compressive loading of sternal chondrocyte-agarose disks has been shown to induce an increase in calcium signaling, upregulation of aggrecan expression, and higher sGAG accumulation; these loading effects were absent in IFT88(orpk) mutant chondrocytes that lack primary cilium [95]. Together, these studies suggest that the primary cilium may contribute in multiple and complex ways to mechanical signal transduction in chondrocytes, and further investigations are needed to clarify the contributions of this proposed mechanosensory organelle.

Deformation of the nucleus in chondrocytes may be important in propagating the cellular response to biophysical stimuli [96]. The connections between the extracellular matrix, integrins, cytoskeleton, LINC complex, and nuclear lamina allow for direct transmission of biophysical forces from the cell exterior to the nucleus and potentially to subnuclear structures. The nucleus in chondrocytes deforms in response to compression of articular cartilage explants [40] and chondrocyte/agarose constructs [97]. Application of osmotic stress to chondrocytes also influences nuclear volume and structure [98], with changes in the nucleus probably reflecting alterations in intracellular macromolecular concentrations [99]. Studies are needed to define how these direct pathways by which biophysical stimuli influence the nucleus contribute to regulation of gene expression by mechanical loading in chondrocytes and stem cells.

The cytoskeleton in articular chondrocytes is primarily composed of actin microfilaments, microtubules, and vimentin intermediate filaments [100]. Disruption of actin microfilaments with cytochalasin $D$ was found to decrease viscoelastic mechanical properties of chondrocytes [101] and to alter chondrocyte nuclear deformation in response to compression of cartilage explants [40]. The actin cytoskeleton in articular chondrocytes has also been shown to undergo reorganization with osmotic stress [70,102], as well as compressive loading and hydrostatic pressure [103]. These studies suggest that the cytoskeleton is involved in the response of chondrocytes to mechanical loading, yet studies directly implicating the cytoskeleton are lacking. Prior work has shown that integrins are involved in responses of chondrocyte-hydrogel constructs to dynamic compressive loading [104,105]. A recent study demonstrated that, when chondrocytes were suspended in agarose and pretreated with a blocking antibody for $\alpha_{\mathrm{v}}$ or $\beta_{1}$ integrin, the increases in sGAG synthesis and sGAG accumulation induced by 24 hours of dynamic compression were disrupted [106]. Linkages between integrins and cytoskeletal components are thought to be integral to mechanotransduction in various cell types [107], but such linkages in chondrocytes have not been well defined. How early signaling events downstream of changes in ion channels, the primary cilium, the nucleus, and the cytoskeleton are propagated into changes in gene expression and matrix synthesis that support chondrogenic differentiation and neo-tissue formation remain open questions for future investigations.

\section{Conclusion}

Mechanically-generated signals appear to play a critical role in the differentiation and maturation of MSCs into a chondrogenic phenotype. Compressive deformational loading of MSC-laden constructs produces a pro-chondrogenic and biosynthetic response that is advantageous for developing MSC-based neotissues for cartilage regeneration and repair, and this system can also be used as a model to better understand the mechanisms of MSC mechanotransduction. Use of more advanced bioreactors, such as those that also incorporate shear and other components of loading, further enhances the chondrogenic response of MSCs to mechanical loading, and better mimics the in vivo environment in which these cartilage neotissues are designed to reside. Knowledge about the mechanisms that transduce macroscopic mechanical forces into intracellular events is increasing with respect to both chondrocytes and chondrogenicallyinduced MSCs. Further delineations about these mechanisms will probably lead to controllable strategies for rapid and effective preconditioning of anatomically shaped MSC-based cartilage replacements.

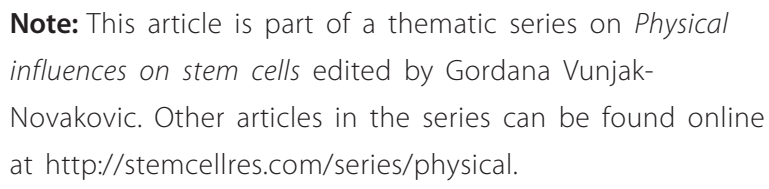

Abbreviations

MSC: Mesenchymal stem cell; sGAG: Sulfated glycosaminoglycan;

TGF $\beta$ : Transforming growth factor beta; TRP: Transient receptor potential.

\section{Competing interests}

The authors declare that they have no competing interests. 


\section{Acknowledgements}

This work was supported by grants from the National Institutes of Health (AR48182, AR50245, AG15768, AR48852, AG40868, and GM08719) and by the Collaborative Research Center, AO Foundation, Davos, Switzerland.

Published: 1 July 2013

\section{References}

1. Estes BT, Gimble JM, Guilak F: Mechanical signals as regulators of stem cell fate. Curr Top Dev Biol 2004, 60:91-126.

2. Aaron RK, Ciombor DM, Wang S, Simon B: Clinical biophysics: the promotion of skeletal repair by physical forces. Ann N Y Acad Sci 2006 1068:513-531

3. Kelly DJ, Jacobs CR: The role of mechanical signals in regulating chondrogenesis and osteogenesis of mesenchymal stem cells. Birth Defects Res C Embryo Today 2010, 90:75-85.

4. McCullen SD, Haslauer CM, Loboa EG: Musculoskeletal mechanobiology: interpretation by external force and engineered substratum. J Biomech 2010, 43:119-127.

5. Wescoe KE, Schugar RC, Chu CR, Deasy BM: The role of the biochemical and biophysical environment in chondrogenic stem cell differentiation assays and cartilage tissue engineering. Cell Biochem Biophys 2008, 52:85-102.

6. Elder $\mathrm{BD}$, Athanasiou KA: Hydrostatic pressure in articular cartilage tissue engineering: from chondrocytes to tissue regeneration. Tissue Eng Part $B$ Rev 2009, 15:43-53.

7. Grad S, Eglin D, Alini M, Stoddart MJ: Physical stimulation of chondrogenic cells in vitro: a review. Clin Orthop Relat Res 2011, 469:2764-2772.

8. Pittenger MF, Mackay AM, Beck SC, Jaiswal RK, Douglas R, Mosca JD, Moorman MA, Simonetti DW, Craig S, Marshak DR: Multilineage potential of adult human mesenchymal stem cells. Science 1999, 284:143-147.

9. Guilak F, Estes BT, Diekman BO, Moutos FT, Gimble JM: Nicolas Andry Award: multipotent adult stem cells from adipose tissue for musculoskeletal tissue engineering. Clin Orthop Relat Res 2010, 2010(468):2530-2540.

10. De Bari C, Dell'Accio F, Tylzanowski P, Luyten FP: Multipotent mesenchymal stem cells from adult human synovial membrane. Arthritis Rheum 2001, 44:1928-1942.

11. Tae SK, Lee SH, Park JS, Im Gl: Mesenchymal stem cells for tissue engineering and regenerative medicine. Biomed Mater 2006, 1:63-71.

12. Matsumoto T, Okabe T, Ikawa T, lida T, Yasuda H, Nakamura H, Wakitani S: Articular cartilage repair with autologous bone marrow mesenchymal cells. J Cell Physiol 2010, 225:291-295.

13. Estes BT, Diekman BO, Gimble JM, Guilak F: Isolation of adipose-derived stem cells and their induction to a chondrogenic phenotype. Nat Protoc 2010, 5:1294-1311.

14. Fan J, Varshney RR, Ren L, Cai D, Wang DA: Synovium-derived mesenchymal stem cells: a new cell source for musculoskeletal regeneration. Tissue Eng Part B Rev 2009, 15:75-86.

15. Guilak F, Butler DL, Goldstein SA: Functional tissue engineering: the role of biomechanics in articular cartilage repair. Clin Orthop Relat Res 2001, 391 (Suppl):S295-S305

16. Mouw JK, Connelly JT, Wilson CG, Michael KE, Levenston ME: Dynamic compression regulates the expression and synthesis of chondrocyte-specific matrix molecules in bone marrow stromal cells. Stem Cells 2007, 25:655-663.

17. Mauck RL, Byers BA, Yuan X, Tuan RS: Regulation of cartilaginous ECM gene transcription by chondrocytes and MSCs in 3D culture in response to dynamic loading. Biomech Model Mechanobiol 2007, 6:113-125.

18. Kisiday JD, Frisbie DD, Mcllwraith CW, Grodzinsky AJ: Dynamic compression stimulates proteoglycan synthesis by mesenchymal stem cells in the absence of chondrogenic cytokines. Tissue Eng Part A 2009, 15:2817-2824.

19. Huang AH, Farrell MJ, Kim M, Mauck RL: Long-term dynamic loading improves the mechanical properties of chondrogenic mesenchymal stem cell-laden hydrogel. Eur Cell Mater 2010, 19:72-85.

20. Li Z, Yao SJ, Alini M, Stoddart MJ: Chondrogenesis of human bone marrow mesenchymal stem cells in fibrin-polyurethane composites is modulated by frequency and amplitude of dynamic compression and shear stress. Tissue Eng Part A 2010, 16:575-584.

21. Thorpe SD, Buckley CT, Vinardell T, O'Brien FJ, Campbell VA, Kelly DJ: The response of bone marrow-derived mesenchymal stem cells to dynamic compression following TGF- $\beta 3$ induced chondrogenic differentiation. Ann Biomed Eng 2010, 38:2896-2909.
22. Schatti O, Grad S, Goldhahn J, Salzmann G, Li Z, Alini M, Stoddart MJ: A combination of shear and dynamic compression leads to mechanically induced chondrogenesis of human mesenchymal stem cells. Eur Cell Mater 2011, 22:214-225.

23. Haugh MG, Meyer EG, Thorpe SD, Vinardell T, Duffy GP, Kelly DJ: Temporal and spatial changes in cartilage-matrix-specific gene expression in mesenchymal stem cells in response to dynamic compression. Tissue Eng Part A 2011, 17:3085-3093.

24. Huang AH, Baker BM, Ateshian GA, Mauck RL: Sliding contact loading enhances the tensile properties of mesenchymal stem cell-seeded hydrogels. Eur Cell Mater 2012, 24:29-45.

25. Bian L, Zhai DY, Zhang EC, Mauck RL, Burdick JA: Dynamic compressive loading enhances cartilage matrix synthesis and distribution and suppresses hypertrophy in hMSC-laden hyaluronic acid hydrogels. Tissue Eng Part A 2012, 18:715-724.

26. Potier E, Noailly J, Ito K: Directing bone marrow-derived stromal cell function with mechanics. J Biomech 2010, 43:807-817.

27. Buschmann MD, Gluzband YA, Grodzinsky AJ, Kimura JH, Hunziker EB: Chondrocytes in agarose culture synthesize a mechanically functional extracellular matrix. J Orthop Res 1992, 10:745-758.

28. Lee DA, Bader DL: The development and characterization of an in vitro system to study strain-induced cell deformation in isolated chondrocytes. In Vitro Cell Dev Biol Anim 1995, 31:828-835.

29. Byers BA, Mauck RL, Chiang IE, Tuan RS: Transient exposure to transforming growth factor beta 3 under serum-free conditions enhances the biomechanical and biochemical maturation of tissueengineered cartilage. Tissue Eng Part A 2008, 14:1821-1834.

30. Mauck RL, Nicoll SB, Seyhan SL, Ateshian GA, Hung CT: Synergistic action of growth factors and dynamic loading for articular cartilage tissue engineering. Tissue Eng 2003, 9:597-611.

31. Kelly TA, Fisher MB, Oswald ES, Tai T, Mauck RL, Ateshian GA, Hung CT: Low-serum media and dynamic deformational loading in tissue engineering of articular cartilage. Ann Biomed Eng 2008, 36:769-779.

32. eCM Journal. www.ecmjournal.org.

33. Ng KW, Mauck RL, Wang CC, Kelly TA, Ho MM, Chen FH, Ateshian GA, Hung $\mathrm{CT}$ : Duty cycle of deformational loading influences the growth of engineered articular cartilage. Cell Mol Bioeng 2009, 2:386-394.

34. Elder SH, Goldstein SA, Kimura JH, Soslowsky LJ, Spengler DM: Chondrocyte differentiation is modulated by frequency and duration of cyclic compressive loading. Ann Biomed Eng 2001, 29:476-482.

35. Struglics A, Hansson M: MMP proteolysis of the human extracellular matrix protein aggrecan is mainly a process of normal turnover. Biochem J 2012, 446:213-223.

36. Lima EG, Bian L, Ng KW, Mauck RL, Byers BA, Tuan RS, Ateshian GA, Hung $C T$ : The beneficial effect of delayed compressive loading on tissueengineered cartilage constructs cultured with TGF- $\beta 3$. Osteoarthr Cartil 2007, 15:1025-1033.

37. Pelttari K, Winter A, Steck E, Goetzke K, Hennig T, Ochs BG, Aigner T, Richter W: Premature induction of hypertrophy during in vitro chondrogenesis of human mesenchymal stem cells correlates with calcification and vascular invasion after ectopic transplantation in SCID mice. Arthritis Rheum 2006, 54:3254-3266

38. Guilak F, Mow VC: The mechanical environment of the chondrocyte: a biphasic finite element model of cell-matrix interactions in articular cartilage. J Biomech 2000, 33:1663-1673.

39. Waldman SD, Couto DC, Grynpas MD, Pilliar RM, Kandel RA: Multi-axia mechanical stimulation of tissue engineered cartilage: review. Eur Cell Mater 2007, 13:66-73. discussion 73-64.

40. Guilak F: Compression-induced changes in the shape and volume of the chondrocyte nucleus. J Biomech 1995, 28:1529-1541.

41. Bryant SJ, Anseth KS, Lee DA, Bader DL: Crosslinking density influences the morphology of chondrocytes photoencapsulated in PEG hydrogels during the application of compressive strain. J Orthop Res 2004, 22:1143-1149.

42. Freeman PM, Natarajan RN, Kimura JH, Andriacchi TP: Chondrocyte cells respond mechanically to compressive loads. J Orthop Res 1994, 12:311-320.

43. Choi JB, Youn I, Cao L, Leddy HA, Gilchrist CL, Setton LA, Guilak F: Zonal changes in the three-dimensional morphology of the chondron under compression: the relationship among cellular, pericellular, and extracellular deformation in articular cartilage. J Biomech 2007, 40:2596-2603. 
44. Kuo CK, Tuan RS: Mechanoactive tenogenic differentiation of human mesenchymal stem cells. Tissue Eng Part A 2008, 14:1615-1627.

45. Connelly JT, Vanderploeg EJ, Mouw JK, Wilson CG, Levenston ME: Tensile loading modulates bone marrow stromal cell differentiation and the development of engineered fibrocartilage constructs. Tissue Eng Part A 2010, 16:1913-1923.

46. Baker BM, Shah RP, Huang AH, Mauck RL: Dynamic tensile loading improves the functional properties of mesenchymal stem cell-laden nanofiber-based fibrocartilage. Tissue Eng Part A 2011, 17:1445-1455.

47. Soltz MA, Ateshian GA: Interstitial fluid pressurization during confined compression cyclical loading of articular cartilage. Ann Biomed Eng 2000 28:150-159.

48. Hall AC, Urban JP, Gehl KA: The effects of hydrostatic pressure on matrix synthesis in articular cartilage. J Orthop Res 1991, 9:1-10.

49. Hung CT, Mauck RL, Wang CC, Lima EG, Ateshian GA: A paradigm for functional tissue engineering of articular cartilage via applied physiologic deformational loading. Ann Biomed Eng 2004, 32:35-49.

50. Park S, Krishnan R, Nicoll SB, Ateshian GA: Cartilage interstitial fluid load support in unconfined compression. J Biomech 2003, 36:1785-1796.

51. Bachrach NM, Mow VC, Guilak F: Incompressibility of the solid matrix of articular cartilage under high hydrostatic pressures. J Biomech 1998, 31:445-451.

52. Toyoda T, Seedhom BB, Kirkham J, Bonass WA: Upregulation of aggrecan and type II collagen mRNA expression in bovine chondrocytes by the application of hydrostatic pressure. Biorheology 2003, 40:79-85.

53. Elder BD, Athanasiou KA: Synergistic and additive effects of hydrostatic pressure and growth factors on tissue formation. PLoS One 2008, 3:e2341.

54. Angele P, Yoo JU, Smith C, Mansour J, Jepsen KJ, Nerlich M, Johnstone B: Cyclic hydrostatic pressure enhances the chondrogenic phenotype of human mesenchymal progenitor cells differentiated in vitro. J Orthop Res 2003, 21:451-457

55. Miyanishi K, Trindade MC, Lindsey DP, Beaupre GS, Carter DR, Goodman SB, Schurman DJ, Smith RL: Effects of hydrostatic pressure and transforming growth factor-beta 3 on adult human mesenchymal stem cell chondrogenesis in vitro. Tissue Eng 2006, 12:1419-1428.

56. Wagner DR, Lindsey DP, Li KW, Tummala P, Chandran SE, Smith RL, Longaker MT, Carter DR, Beaupre GS: Hydrostatic pressure enhances chondrogenic differentiation of human bone marrow stromal cells in osteochondrogenic medium. Ann Biomed Eng 2008, 36:813-820.

57. Miyanishi K, Trindade MC, Lindsey DP, Beaupre GS, Carter DR, Goodman SB Schurman DJ, Smith RL: Dose- and time-dependent effects of cyclic hydrostatic pressure on transforming growth factor-beta3-induced chondrogenesis by adult human mesenchymal stem cells in vitro. Tissue Eng 2006, 12:2253-2262

58. Finger AR, Sargent CY, Dulaney KO, Bernacki SH, Loboa EG: Differentia effects on messenger ribonucleic acid expression by bone marrowderived human mesenchymal stem cells seeded in agarose constructs due to ramped and steady applications of cyclic hydrostatic pressure. Tissue Eng 2007, 13:1151-1158.

59. Puetzer J, Williams J, Gillies A, Bernacki S, Loboa EG: The effects of cyclic hydrostatic pressure on chondrogenesis and viability of human adiposeand bone marrow-derived mesenchymal stem cells in three-dimensional agarose constructs. Tissue Eng Part A 2013, 19:299-306.

60. Li J, Zhao Z, Yang J, Liu J, Wang J, Li X, Liu Y: p38 MAPK mediated in compressive stress-induced chondrogenesis of rat bone marrow MSCs in 3D alginate scaffolds. J Cell Physiol 2009, 221:609-617.

61. Li J, Wang J, Zou Y, Zhang Y, Long D, Lei L, Tan L, Ye R, Wang X, Zhao Z The influence of delayed compressive stress on TGF- $\beta 1$-induced chondrogenic differentiation of rat BMSCs through Smad-dependent and Smad-independent pathways. Biomaterials 2012, 33:8395-8405.

62. Urban JP, Hall AC, Gehl KA: Regulation of matrix synthesis rates by the ionic and osmotic environment of articular chondrocytes. J Cell Physiol 1993, 154:262-270

63. Hopewell B, Urban JP: Adaptation of articular chondrocytes to changes in osmolality. Biorheology 2003, 40:73-77.

64. Negoro K, Kobayashi S, Takeno K, Uchida K, Baba H: Effect of osmolarity on glycosaminoglycan production and cell metabolism of articular chondrocyte under three-dimensional culture system. Clin Exp Rheumatol 2008, 26:534-541.

65. Xu X, Urban JP, Tirlapur UK, Cui Z: Osmolarity effects on bovine articular chondrocytes during three-dimensional culture in alginate beads. Osteoarthr Cartil 2010, 18:433-439.
66. Oswald ES, Ahmed HS, Kramer SP, Bulinski JC, Ateshian GA, Hung CT: Effects of hypertonic $(\mathrm{NaCl})$ two-dimensional and three-dimensional culture conditions on the properties of cartilage tissue engineered from an expanded mature bovine chondrocyte source. Tissue Eng Part C Methods 2011, 17:1041-1049.

67. Tew SR, Peffers MJ, McKay TR, Lowe ET, Khan WS, Hardingham TE, Clegg PD: Hyperosmolarity regulates SOX9 mRNA posttranscriptionally in human articular chondrocytes. Am J Physiol Cell Physiol 2009, 297:C898-C906.

68. Peffers MJ, Milner PI, Tew SR, Clegg PD: Regulation of SOX9 in normal and osteoarthritic equine articular chondrocytes by hyperosmotic loading. Osteoarthr Cartil 2010, 18:1502-1508.

69. Coleman JL, Widmyer MR, Leddy HA, Utturkar GM, Spritzer CE, Moorman CT 3rd, Guilak F, Defrate LE: Diurnal variations in articular cartilage thickness and strain in the human knee. J Biomech 2013, 46:541-547.

70. Chao PH, West AC, Hung CT: Chondrocyte intracellular calcium, cytoskeletal organization, and gene expression responses to dynamic osmotic loading. Am J Physiol Cell Physiol 2006, 291:C718-C725.

71. Wuertz K, Godburn K, Neidlinger-Wilke C, Urban J, latridis JC: Behavior of mesenchymal stem cells in the chemical microenvironment of the intervertebral disc. Spine (Phila Pa 1976) 2008, 33:1843-1849.

72. Liang C, Li H, Tao Y, Zhou X, Li F, Chen G, Chen Q: Responses of human adipose-derived mesenchymal stem cells to chemical microenvironment of the intervertebral disc. J Trans/ Med 2012, 10:49.

73. Caron MM, van der Windt AE, Emans PJ, van Rhijn LW, Jahr H, Welting TJ: Osmolarity determines the in vitro chondrogenic differentiation capacity of progenitor cells via nuclear factor of activated T-cells 5. Bone 2013, 53:94-102.

74. Albro MB, Cigan AD, Nims RJ, Yeroushalmi KJ, Oungoulian SR, Hung CT, Ateshian GA: Shearing of synovial fluid activates latent TGF-beta. Osteoarthr Cartil 2012, 20:1374-1382.

75. Vunjak-Novakovic G, Martin I, Obradovic B, Treppo S, Grodzinsky AJ, Langer $R$, Freed LE: Bioreactor cultivation conditions modulate the composition and mechanical properties of tissue-engineered cartilage. J Orthop Res 1999, 17:130-138

76. Pazzano D, Mercier KA, Moran JM, Fong SS, DiBiasio DD, Rulfs JX, Kohles SS, Bonassar LJ: Comparison of chondrogensis in static and perfused bioreactor culture. Biotechnol Prog 2000, 16:893-896.

77. Vunjak-Novakovic G, Obradovic B, Martin I, Freed LE: Bioreactor studies of native and tissue engineered cartilage. Biorheology 2002, 39:259-268.

78. Goncalves A, Costa P, Rodrigues MT, Dias IR, Reis RL, Gomes ME: Effect of flow perfusion conditions in the chondrogenic differentiation of bone marrow stromal cells cultured onto starch based biodegradable scaffolds. Acta Biomater 2011, 7:1644-1652.

79. da Silva ML A, Martins A, Costa-Pinto AR, Correlo VM, Sol P, Bhattacharya M, Faria S, Reis RL, Neves NM: Chondrogenic differentiation of human bone marrow mesenchymal stem cells in chitosan-based scaffolds using a flow-perfusion bioreactor. J Tissue Eng Regen Med 2011, 5:722-732.

80. Valonen PK, Moutos FT, Kusanagi A, Moretti MG, Diekman BO, Welter JF, Caplan Al, Guilak F, Freed LE: In vitro generation of mechanically functional cartilage grafts based on adult human stem cells and 3D-woven poly (epsilon-caprolactone) scaffolds. Biomaterials 2010, 31:2193-2200.

81. Barrett-Jolley R, Lewis R, Fallman R, Mobasheri A: The emerging chondrocyte channelome. Front Physiol 2010, 1:135.

82. Phan MN, Leddy HA, Votta BJ, Kumar S, Levy DS, Lipshutz DB, Lee SH, Liedtke W, Guilak F: Functional characterization of TRPV4 as an osmotically sensitive ion channel in porcine articular chondrocytes. Arthritis Rheum 2009, 60:3028-3037.

83. Browning JA, Saunders K, Urban JP, Wilkins RJ: The influence and interactions of hydrostatic and osmotic pressures on the intracellular milieu of chondrocytes. Biorheology 2004, 41:299-308.

84. Han SK, Wouters W, Clark A, Herzog W: Mechanically induced calcium signaling in chondrocytes in situ. J Orthop Res 2012, 30:475-481.

85. Pingguan-Murphy B, El-Azzeh M, Bader DL, Knight MM: Cyclic compression of chondrocytes modulates a purinergic calcium signalling pathway in a strain rate- and frequency-dependent manner. J Cell Physiol 2006, 209:389-397.

86. Fitzgerald JB, Jin M, Grodzinsky AJ: Shear and compression differentially regulate clusters of functionally related temporal transcription patterns in cartilage tissue. J Biol Chem 2006, 281:24095-24103.

87. Mouw JK, Imler SM, Levenston ME: lon-channel regulation of chondrocyte matrix synthesis in 3D culture under static and dynamic compression. Biomech Model Mechanobiol 2007, 6:33-41. 
88. Natoli RM, Skaalure S, Bijlani S, Chen KX, Hu J, Athanasiou KA: Intracellular Na $(+)$ and $\mathrm{Ca}(2+)$ modulation increases the tensile properties of developing engineered articular cartilage. Arthritis Rheum 2010, 62:1097-1107.

89. Hoey DA, Downs ME, Jacobs CR: The mechanics of the primary cilium: an intricate structure with complex function. J Biomech 2012, 45:17-26.

90. Wilsman NJ: Cilia of adult canine articular chondrocytes. J Ultrastruct Res 1978, 64:270-281.

91. Poole CA, Flint MH, Beaumont BW: Analysis of the morphology and function of primary cilia in connective tissues: a cellular cybernetic probe? Cell Motil 1985, 5:175-193.

92. Whitfield JF: The solitary (primary) cilium - a mechanosensory toggle switch in bone and cartilage cells. Cell Signal 2008, 20:1019-1024.

93. Muhammad H, Rais Y, Miosge N, Ornan EM: The primary cilium as a dual sensor of mechanochemical signals in chondrocytes. Cell Mol Life Sci 2012, 69:2101-2107

94. McGlashan SR, Jensen CG, Poole CA: Localization of extracellular matrix receptors on the chondrocyte primary cilium. J Histochem Cytochem 2006, 54:1005-1014

95. Wann AK, Zuo N, Haycraft CJ, Jensen CG, Poole CA, McGlashan SR, Knight MM: Primary cilia mediate mechanotransduction through control of ATPinduced $\mathrm{Ca}^{2+}$ signaling in compressed chondrocytes. FASEB J 2012, 26:1663-1671.

96. Martins RP, Finan JD, Guilak F, Lee DA: Mechanical regulation of nuclear structure and function. Annu Rev Biomed Eng 2012, 14:431-455.

97. Lee DA, Knight MM, Bolton JF, Idowu BD, Kayser MV, Bader DL: Chondrocyte deformation within compressed agarose constructs at the cellular and sub-cellular levels. J Biomech 2000, 33:81-95.

98. Finan JD, Chalut KJ, Wax A, Guilak F: Nonlinear osmotic properties of the cell nucleus. Ann Biomed Eng 2009, 37:477-491.

99. Finan JD, Guilak F: The effects of osmotic stress on the structure and function of the cell nucleus. J Cell Biochem 2010, 109:460-467.

100. Blain EJ: Involvement of the cytoskeletal elements in articular cartilage homeostasis and pathology. Int J Exp Pathol 2009, 90:1-15

101. Trickey WR, Vail TP, Guilak F: The role of the cytoskeleton in the viscoelastic properties of human articular chondrocytes. J Orthop Res 2004, 22:131-139.

102. Erickson GR, Northrup DL, Guilak F: Hypo-osmotic stress induces calciumdependent actin reorganization in articular chondrocytes. Osteoarthr Cartil 2003, 11:187-197.

103. Knight MM, Toyoda T, Lee DA, Bader DL: Mechanical compression and hydrostatic pressure induce reversible changes in actin cytoskeletal organisation in chondrocytes in agarose. J Biomech 2006, 39:1547-1551.

104. Giannoni P, Siegrist M, Hunziker EB, Wong M: The mechanosensitivity of cartilage oligomeric matrix protein (COMP). Biorheology 2003, 40:101-109.

105. Chowdhury TT, Appleby RN, Salter DM, Bader DA, Lee DA: Integrinmediated mechanotransduction in IL-1 beta stimulated chondrocytes. Biomech Model Mechanobiol 2006, 5:192-201.

106. Chai DH, Arner EC, Griggs DW, Grodzinsky AJ: Alphav and beta1 integrins regulate dynamic compression-induced proteoglycan synthesis in $3 \mathrm{D}$ gel culture by distinct complementary pathways. Osteoarthr Cartil 2010, 18:249-256

107. Wang $\mathrm{JH}$, Thampatty BP: An introductory review of cell mechanobiology. Biomech Model Mechanobiol 2006, 5:1-16.

\section{doi:10.1186/scrt211}

Cite this article as: O'Conor et al:: Mechanical regulation of

chondrogenesis. Stem Cell Research \& Therapy 2013 4:61. 